\title{
VIEWS OF JUNIOR HIGH SCHOOL TEACHERS TOWARD ONLINE LEARNING
}

\author{
JUHJI ${ }^{1}$, ADANG SUTARMAN ${ }^{2}$, SUPADIYO RAHARJO 3 \\ UIN Sultan Maulana Hasanuddin Banten ${ }^{1}$, SMPN 1 Pamarayan, Kabupaten Serang, \\ Provinsi Banten², SMPN 2 Cikande, Kabupaten Serang, Provinsi Banten ${ }^{3}$ \\ Email: juhji@uinbanten.ac.id ${ }^{1}$, adangsutarman@gmail.com², \\ supadiyoraharjo@gmail.com ${ }^{3}$ \\ Article History \\ Received April 10, 2021; Revised May 02, 2021; Accepted June 3, 2021
}

\begin{abstract}
Views of Junior High School Toward Online Learning
This study aims to explore the views of junior high school teachers on online learning. The survey method is used to gather the views of junior high school teachers in Serang Regency. Seventy-nine teachers who had taught at the junior high school level, consisting of 37 male teachers and 42 female teachers were asked questions via Google Form. The results showed the use of Whatsapp Group is more dominant than other online media because its use is more familiar and accessible to students. In general, teacher's views on online learning are moderate, although there are some items that indicate a high category. Further discussions regarding online learning are presented at the end and some of the advantages of online learning are discussed in depth.
\end{abstract}

Keywords: Views of Junior High School, Online Learning

\begin{abstract}
Abstrak: Pandangan para Guru Sekolah Menengah Pertama terhadap Pembelajaran Daring

Penelitian ini bertujuan mengeksplorasi pandangan para guru sekolah menengah pertama terhadap pembelajaran daring. Metode survei digunakan untuk mengumpulkan pandangan para guru sekolah menengah pertama di Kabupaten Serang. Tujuh puluh sembilan guru yang telah mengajar di tingkat sekolah menengah pertama, terdiri atas 37 guru laki-laki dan 42 guru perempuan diberikan pertanyaan melalui Google Form. Hasil penelitian menunjukkan penggunaan Whatsapp Group lebih dominan daripada media daring yang lainnya karena penggunaannya lebih familiar dan mudah dijangkau peserta didik. Secara umum, pandangan guru terhadap pembelajaran daring berkategori sedang, meski ada beberapa item yang menunjukkan kategori tinggi. Diskusi lanjut terkait pembelajaran daring disajikan pada bagian akhir dan beberapa keunggulan pembelajaran daring dibahas secara mendalam.
\end{abstract}

Kata Kunci: Pandangan Guru SMP, Pembelajaran Daring

\section{PENDAHULUAN}

embelajaran daring atau dikenal juga dengan pembelajaran jarak jauh (PJJ) bukanlah sesuatu yang baru (Pohan, 2020), karena sudah diterapkan oleh beberapa Guru sebelum masa pandemi covid-19. Meskipun secara umum, 
pembelajaran daring dikenal di masyakarat pendidikan saat pandemi covid-19 melanda Indonesia, bahkan dunia. Hal ini karena semua sekolah tidak diperkenankan melakukan proses pembelajaran secara tatap muka (luring), sehingga proses pembelajaran tetap dilangsungkan namun dalam jarak jauh. Pembelajaran daring adalah pembelajaran yang dilakukan secara virtual (Nahdi dan Jatisunda, 2020; Syarifudin, 2020) dimana guru dan peserta didik berada pada tempat berbeda. Guru harus menyadari apa yang mereka ajarkan kepada peserta didik berdasarkan hakikat belajar melalui berbagai media yang digunakan seperti Whatsapp Group (Kheryadi, 2018; Rosenberg dan Asterhan, 2018; Surani dan Chaerudin, 2019), Youtube, Google Classroom, Google Meet (Septantiningtyas et al., 2021), Zoom atau yang lainnya sehingga pembelajaran yang dilakukan tetap mendidik, menyenangkan, dan tidak memberikan kejenuhan kepada peserta didik. Tetapi, laporan beberapa penelitian menunjukkan adanya kejenuhan peserta didik dalam mengikuti pembelajaran daring (Pawicara dan Conilie, 2020). Faktor-faktor seperti penyajian materi selama proses pembelajaran yang dilakukan secara monoton, banyaknya tugas yang diberikan, dan ketidakpahaman peserta didik terhadap materi yang disampaikan menyebabkan kemalasan, kehilangan semangat, kelelahan, kebosanan, dan kejenuhan.

Paradigma baru lingkungan belajar mengajar dalam era reformasi pembelajaran abad 21 menyerukan pendekatan pembelajaran yang berpusat pada peserta didik, dirancang dengan baik di kelas (Nuangchalerm et al., 2020) termasuk dalam pembelajaran daring. Pandangan holistik harus dimunculkan dalam pembelajaran kontemporer, sehingga metode yang disematkan menjadi terintegrasi meski dalam konteks ruang kelas yang berbeda. Secara operasional, kemampuan mengelola pembelajaran daring mencakup tiga fungsi pengelolaan seperti perencanaan, pelaksanaan, dan pengendalian (Ahmad, 2020). Menurut Tarihoran dan Cendana (2020), pembelajaran yang efektif didukung dengan pengelolaan kelas yang baik. Artinya, pengelolaan kelas yang baik dapat dilakukan oleh Guru yang berkompeten dalam mengatur kondisi dan situasi pembelajaran daring agar tetap berjalan optimal dan efektif, meski terdapat kendala saat proses pembelajaran dilangsungkan. Namun, beberapa penelitian melaporkan adanya berbagai kendala pembelajaran daring (Asmuni, 2020; Hutauruk, 2020; Putria et al., 2020; Rigianti, 2020; Widodo \& Nursaptini, 2020) seperti aplikasi pembelajaran, jaringan internet, pengelolaan pembelajaran, penilaian, pengawasan, tidak semua peserta didik memiliki handphone, masih banyak orang tua sibuk bekerja, dan sebagainya.

Indonesia melalui Kementerian Pendidikan dan Kebudayaan menerbitkan Surat Keputusan Menteri Pendidikan dan Kebudayaan Republik Indonesia Nomor 719/P/2020 tentang Pedoman Pelaksanaan Kurikulum pada Satuan Pendidikan dalam Kondisi Khusus bertujuan agar memberikan fleksibilitas bagi satuan pendidikan untuk menentukan kurikulum yang sesuai dengan kebutuhan pembelajaran peserta didik di masa pandemi covid-19. Kurikulum ini mengakibatkan 
peserta didik memiliki pengetahuan dalam kaitannya dengan kehidupan abad 21 dimana akses kemudahan informasi sangat cepat didapat tanpa batas karena mereka dapat belajar dimana saja dan kapan saja. Meskipun demikian, kurikulum membutuhkan peserta didik untuk memiliki pengetahuan dan mengaplikasikan pembelajaran yang efektif. Oleh karena itu, pembelajaran daring yang dilakukan harus didesain dengan menggunakan metode yang berbeda berdasarkan konteks peserta didik agar mereka mampu terlibat aktif, berpikir kritis, dan menyenangkan. Tetapi, beberapa penelitian melaporkan adanya kejenuhan dalam pembelajaran yang dilakukan selama masa pandemi covid-19 ini (Pawicara \& Conilie, 2020; Ningrum et al., 2020; Kurnia, 2021).

Guru dapat meningkatkan kompetensi pedagogik dan kompetensi profesionalnya melalui berbagai macam kegiatan pembelajaran seperti pendidikan dan latihan, workshop media pembelajaran, training pembelajaran abad 21, kelompok kerja guru, komunitas guru, dan sebagainya untuk meningkatkan keterampilan dan kompetensi mereka. Guru adalah faktor penting untuk membentuk kualitas pendidikan (Juhji, 2016), guru bertindak sebagai agen perubahan untuk pembelajaran peserta didik menjadi efektif (Prachagool et al., 2016; Hasbullah et al., 2019). Kunci keberhasilan peserta didik dalam pembelajaran daring bersumber dari proses pembelajaran yang dilakukan dan kualitas peserta didik berasal dari kualitas guru. Artinya, guru harus beradaptasi dan mengadopsi strategi pembelajaran agar sesuai dengan era perubahan sosial (Tondeur et al., 2019; Kinloch et al., 2020; Supardi et al., 2021). Adaptasi guru terhadap pembelajaran abad 21 yang dilakukan secara daring merupakan sebuah keniscayaan agar mereka tidak ketinggalan arah. Namun, beberapa guru menyikapi pembelajaran daring beraneka ragam, ada sekolah yang langsung adaptif dengan menyediakan segala perangkat pembelajaran yang mudah diakses peserta didik, melengkapi sarana dan prasarana yang mendukung, dan ada juga yang terken dala jaringan internet, mahalnya kuota, partisipasi orang tua dalam memberikan pengawasan terhadap anak-anak mereka, dan sebagainya.

Penelitian ini bertujuan mengeksplorasi pandangan para guru sekolah menengah pertama terhadap pembelajaran daring. Penelitian ini penting dilakukan agar pembelajaran jarak jauh yang dilaksanakan tidak hilang dari "ruh belajar" sehingga peserta didik tetap merasakan kenyamanan dalam belajar mereka dan aktif mengikuti proses pembelajaran karena dilakukan secara asik, menyenangkan, dan tidak membosankan. Lebih penting lagi, pembelajaran daring memberikan edukasi yang bermakna bukan hanya sekadar transfer of knowledge belaka.

\section{METODE PENELITIAN}

Metode survei digunakan untuk mengumpulkan pandangan para guru sekolah menengah pertama di Kabupaten Serang terhadap pembelajaran daring selama pandemi covid-19. Para guru yang menjadi peserta penelitian tergabung dalam unit 
tugas Seksi Pendidikan Agama Islam Kementerian Agama Kantor Kabupaten Serang Provinsi Banten. Unit tugas ini mencakup beberapa sekolah yang tersebar ke dalam wilayah masing-masing, sehingga pengontrolannya tidak dilakukan oleh satu orang pengawas. Tujuh puluh sembilan guru dari 32 sekolah yang telah mengajar di tingkat sekolah menengah pertama yang terdiri atas 37 guru laki-laki dan 42 guru perempuan diberikan pertanyaan melalui Google Form. Tiga puluh dua sekolah tersebut meliputi: SMP Al-Khairiyah 2 Cikeusal, SMP Bina Mandiri, SMP Dian Nusantara, SMP IT Al-Izzah, SMP Muhammadiyah Pontang, SMP Muhammadiyah Tirtayasa, SMP PGRI Kragilan, SMP PGRI Tunjungteja, SMP Plus Assa'adah Dahu Cikeusal, SMPN Satap Cipinang, SMPN Satap Tenjoayu 2, SMPN Satap Catang, SMPN Satap Cidahu, SMPN 1 Bandung, SMPN 2 Bandung, SMPN 1 Cikeusal, SMPN 2 Cikeusal, SMPN 3 Cikeusal, SMPN 2 Ciruas, SMPN 3 Ciruas, SMPN 1 Kragilan, SMPN 2 Kragilan, SMPN 3 Kragilan, SMPN 4 Kragilan, SMPN 1 Pamarayan, SMPN 3 Pamarayan, SMPN 1 Petir, SMPN 1 Tirtayasa, SMPN 1 Tunjung Teja, SMPN 2 Tunjung Teja, SMPN 2 Pontang, dan SMPN 3 Pontang. Informasi demograsi responden dapat dilihat seperti pada Tabel 1.

Tabel 1. Informasi Demografi Peserta

\begin{tabular}{l|ccc}
\hline \multicolumn{2}{l}{ Informasi } & Frekuensi & Persen \\
\hline Jenis Kelamin & Laki-laki & 37 & 46.84 \\
Usia & Perempuan & 42 & 53.16 \\
& Di bawah 30 tahun & 5 & 6.33 \\
& 31 - 40 tahun & 18 & 22.78 \\
Lama Mengajar & $41-50$ tahun & 50 & 63.29 \\
& Di atas 50 tahun & 6 & 7.59 \\
& Di bawah 10 tahun & 17 & 21.52 \\
& $11-20$ tahun & 51 & 64.56 \\
& Di atas 20 tahun & 11 & 13.92 \\
\hline
\end{tabular}

Guru dalam penelitian ini sebagian besar merupakan guru yang memiliki pengalaman mengajar di atas 10 tahun sebanyak 62 orang $(51+11)$ atau 78.48 persen, sedangkan guru yang memiliki pengalaman mengajar kurang dari 10 tahun sebanyak 17 orang (21.52 persen). Mereka diberikan pertanyaan yang sama terkait pembelajaran daring yang dilakukan mereka.

\section{Instrumen Penelitian}

Instrumen penelitian yang digunakan untuk mengeksplorasi pandangan guru terhadap pembelajaran daring berupa kuesioner atau angket. Skala lima peringkat dibuat untuk mengumpulkan pemahaman guru dalam item yang bebas, kuesioner diadaptasi dari Panduan Pengembangan dan Penyelenggaraan Kuliah Daring Indonesia Terbuka dan Terpadu (Kementerian Pendidikan dan Kebudayaan, 2014) untuk mencari pandangan guru sekolah menengah pertama tentang pembelajaran daring. Informasi demografi peserta ditanyakan pada bagian awal mencakup jenis kelamin, usia, lama mengajar, kemudian pada bagian kedua ditanyakan pandangan 
mereka tentang pembelajaran daring. Sepuluh item dijawab terbatas dan lima item dijawab bebas oleh guru melalui Google Form.

\section{Pengumpulan Data}

Data dikumpulkan dalam pandangan guru terhadap pembelajaran daring di Kabupaten Serang, yang dilaksanakan pada 2 minggu bulan November 2020 yakni pada tanggal 1 November 2020 hingga 14 November 2020. Semua peserta melengkapi kuesioner, memeriksa ulang pengisian form. Peneliti berada di dalam jaringan untuk menanggapi dan memberikan respon terhadap jawaban mereka. Kemudian, data diperoleh dan diperiksa ulang kelengkapannya. Data dianalisis secara manual dengan bantuan Ms Excell untuk melihat rata-rata, simpangan baku, dan persentase. Wawancara disajikan dalam pandangan guru terhadap pembelajaran daring.

\section{Analisis Data}

Data dianalisis secara statistik deskriptif, rata-rata, simpangan baku, dan persentase. Pandangan guru sekolah menengah pertama terhadap pembelajaran daring dapat dihitung dan ditafsirkan dengan menunjukkan ke dalam 5 tingkat ratarata untuk menafsirkan: sangat tinggi $(4,51-5,00)$, tinggi $(3,51-4,00)$, sedang $(2,51$ $3,50)$, rendah (1,51-2,50), dan sangat rendah (1,00-1,50). Interpretasinya diwakili oleh tingkat tampilan dan informasi deskriptif yang dapat ditampilkan dalam detail rata-rata, tingkat tampilan di setiap item.

\section{HASIL PENELITIAN DAN PEMBAHASAN}

Hasil penelitian terkait pandangan guru sekolah menengah pertama terhadap pembelajaran daring dapat dilihat pada Tabel 2.

Tabel 2. Pandangan Guru Sekolah Menengah Pertama terhadap Pembelajaran Daring

\begin{tabular}{|c|c|c|c|}
\hline Item & $\begin{array}{l}\text { Rata- } \\
\text { rata }\end{array}$ & $\begin{array}{l}\text { Standar } \\
\text { Deviasi }\end{array}$ & Ket. \\
\hline Meningkatkan ketersediaan layanan pendidikan & 2.95 & 1.23 & Sedang \\
\hline Meningkatkan keterjangkauan layanan pendidikan & 3.20 & 1.20 & Sedang \\
\hline $\begin{array}{l}\text { Meningkatkan mutu dan relevansi layanan } \\
\text { pendidikan }\end{array}$ & 3.13 & 1.27 & Sedang \\
\hline $\begin{array}{l}\text { Meningkatkan kesamaan dalam mendapatkan mutu } \\
\text { layanan pendidikan }\end{array}$ & 3.35 & 1.33 & Sedang \\
\hline $\begin{array}{l}\text { Meningkatkan keterjaminan mendapatkan mutu } \\
\text { layanan pendidikan yang baik }\end{array}$ & 3.52 & 1.44 & Tinggi \\
\hline $\begin{array}{l}\text { Meningkatkan kemandirian dan tanggung jawab } \\
\text { peserta didik }\end{array}$ & 3.10 & 1.22 & Sedang \\
\hline $\begin{array}{l}\text { Memungkinkan interaksi langsung di media yang } \\
\text { digunakan }\end{array}$ & 3.37 & 1.36 & Sedang \\
\hline $\begin{array}{l}\text { Merekam jejak penggunaan materi yang } \\
\text { disampaikan }\end{array}$ & 3.56 & 1.44 & Tinggi \\
\hline Mengonstruk pengetahuan peserta didik & 3.51 & 1.39 & Tinggi \\
\hline $\begin{array}{l}\text { Mengkreasikan dan menginovasi metode } \\
\text { pembelajaran yang digunakan }\end{array}$ & 3.33 & 1.30 & Sedang \\
\hline
\end{tabular}


Berdasarkan Tabel 2, guru mengekspresikan padangan mereka dalam tingkat yang berbeda antara rendah dan tinggi. Pandangan guru terhadap pembelajaran daring menunjukkan pemikiran positif dan cenderung sedang pada item tertentu, meski pada item-item yang lainnya menunjukkan pandangan yang tinggi. Pandangan guru sekolah menengah pertama terhadap pembelajaran daring kategori sedang terdapat pada item 1, 2, 3, 4, 6, 7, dan 10. Artinya menurut pandangan mereka bahwa pembelajaran daring mampu: meningkatkan layanan pendidikan, meningkatkan keterjangkauan layanan pendidikan, meningkatkan mutu dan relevansi layanan pendidikan, meningkatkan kemandirian dan tanggung jawab peserta didik, memungkinkan interaksi langsung di media yang digunakan, serta mengkreasikan dan menginovasi metode pembelajaran yang digunakan.

Pandangan guru sekolah menengah pertama terhadap pembelajaran daring kategori tinggi ditunjukkan pada item 5, 8, dan 9 (Tabel 2). Artinya, menurut mereka bahwa pembelajaran daring mampu meningkatkan keterjaminan mendapatkan mutu layanan pendidikan yang baik, merekam jejak penggunaan materi yang disampaikan, dan mengkonstruk pengetahuan peserta didik. Refleksi empiris guru tentang pembelajaran daring dengan berbagai media yang digunakan dapat dilihat pada hasil jawaban bebas berikut ini:

“Saya menggunakan Whatsapp Group, karena hampir semua siswa siswi mempunyai handphone android dan menggunakan aplikasi WA.Guru tetap bisa menerapkan model pembelajaran yang diinginkan melalui WA seperti flipped classroom, problem based learning, sole, project based learning, dan model pembelajaran lainnya. Contoh pembelajaran tersebut bisa membantu memvariasikan kegiatan pembelajaran kepada siswa. Diharapkan siswa tidak cepat bosan dan tetap semangat dalam kegiatan belajar mengajar secara daring di masa pandemi ini" (Guru A).

"Kami menggunakan Google Classroom, lebih mudah digunakan dan terintegrasi dengan pengwasan kurikulm sekolah dan fasilitas tools pembelajarannya lengkap" (Guru B).

"Saya menggunakan Facebook sebagai media daring, karena siswa lebih mudah menggunakan aplikasi ini daripada aplikasi yang lain" (Guru C).

"Untuk menentukan kompetensi sikap, pengetahuan, dan keterampilan siswa melalui pembelajaran daring, siswa perlu juga diberi pendidikan karakter atau keterampilan yang dapat dipraktikkan di rumah masingmasing. Apabila pembelajaran keterampilan tersebut membutuhkan alat dan bahan, usahakan yang umum tersedia di rumah, tidak perlu keluar rumah" (Guru D)

"Pembelajaran yang dilakukan jangan terlalu berfokus pada aspek akademik, tetapi ada kontrol pada keterampilan hidup, karakter, dan sebagainya. persiapan guru dalam menghadapi sistem pembelajaran yang berani (online) menjadi salah satu faktor hambatan dalam pembelajaran di rumah. Ini suatu hal yang mendadak, guru mana yang 
dipaksa melakukan pembelajaran online yang sebelumnya tidak pernah dipersiapkan oleh guru" (Guru E).

Guru sekolah menengah pertama menerapkan pembelajaran daring sebagai bentuk tindakan pemutus penyebaran virus covid-19, dapat menggunakan semua media yang dimiliki seperti Whatsapp Group, Facebook, Youtube, dan Google Classroom. Selain itu, ada juga guru yang menggunakan Zoom dan Google Meet dalam melakukan pembelajaran daring, meski terbatas pada sekolah-sekolah tertentu saja. Berdasarkan data, penggunaan Whatsapp lebih dominan daripada media yang lainnya. Alasannya, karena peserta didik lebih familiar dengan media tersebut dan mudah digunakan. Meskipun demikian, guru harus lebih memiliki pemahaman yang holistik dan membuat pola pikir kreatif agar pembelajaran daring yang dilakukan benar-benar memiliki makna.

Pandangan guru sekolah menengah pertama terhadap pembelajaran daring beraneka ragam. Temuan menunjukkan bahwa mereka memiliki pandangan dan refleksi berbeda-beda. Secara umum, mereka berpandangan sedang terhadap pembelajaran daring. Artinya, menurut pandangan mereka bahwa pembelajaran daring mampu meningkatkan layanan pendidikan. Ini sejalan dengan pendapatnya Widayati et al (2020) bahwa pembelajaran daring cukup efektif dan efesien dalam menggantikan perkuliahan tatap muka. Artinya, pembelajaran daring yang dilakukan mampu meningkatkan layanan pendidikan di semua lembaga pendidikan, tidak terbatas pada ruang kelas. Selain itu, pembelajaran daring juga meningkatkan keterjangkauan layanan pendidikan (Mustofa et al., 2019; Nurhasanah, 2020; Yohana et al., 2020).

Pembelajaran daring juga mampu meningkatkan mutu dan relevansi layanan pendidikan. Pandangan mereka terhadap item ini berkategori sedang. Menurut Santika (2020), kondisi pandemi Covid-19 telah menjadi tantangan dunia pendidikan agar pembelajaran daring tidak menghilangkan ruh karakter peserta didik. Strategi pembelajaran yang ditawarkannya adalah menggunakan strategi multiplle intelligences berbasis portofolio. Guru dituntut bukan hanya sekadar menyampaikan materi pelajaran namun diharapkan menyisipkan muatan karakter peserta didik saat pembelajaran daring sehingga mutu pendidikan tetap terjaga meskipun sedang dalam masa wabah pandemi. Selain itu, pembelajaran daring juga mampu meningkatkan kemandirian dan tanggung jawab peserta didik. Peserta didik perlu diajarkan bentuk tanggung jawab. Tanggung jawab merupakan karakter yang perlu dibiasakan dan ditanamkan pada peserta didik (Rukiyati et al., 2014; Omeri, 2015), dan merupakan nilai-nilai karakter yang perlu dikembangkan. Penanaman tanggung jawab pada peserta didik sejalan dengan pendapatnya Widayati et al (2020) bahwa pembelajaran daring mampu meningkatkan gairah dan tanggungjawab peserta didik dalam mengerjakan tugas-tugasnya secara tepat waktu. 
Selain itu, pembelajaran daring juga memungkinkan interaksi langsung di media yang digunakan (Khasanah dan Sari, 2021; Naserly, 2020). Kecanggihan media mampu membawa peserta didik dan guru untuk berinteraksi langsung terkait materi pelajaran yang disampaikan. Peserta didik dapat bertanya terhadap materi yang sulit dipahami, dan guru memberikan jawaban langsung terhadap pertanyaanpertanyaan yang diajukan peserta didik. Adanya interaksi dua arah memungkinkan pembelajaran daring yang dilakukan tidak menjadikan kejenuhan belajar. Sehingga keberhasilan pembelajaran daring tergantung pada aktivitas dan respon dari peserta didik. Pembelajaran daring juga mampu mengkreasikan dan menginovasi metode pembelajaran yang digunakan. Artinya, guru tidak hanya sebatas menggunakan media yang sama sehingga terkesan monoton. Guru dituntut untuk melakukan kreativitas dan inovasi-inovasi dalam metode dan media pembelajaran yang digunakan.

Pandangan guru sekolah menengah pertama berkategori tinggi terhadap pembelajaran daring terdapat pada item 5, 8, dan 9. Pembelajaran daring mampu meningkatkan keterjaminan mendapatkan mutu layanan pendidikan yang baik. Artinya, peserta didik mendapatkan mutu layanan pendidikan yang baik dengan penggunaan media yang bervariasi dan metode yang tidak monoton. Beberapa penelitian melaporan penggunaan metode dan media bervariasi mampu menghasilkan hasil belajar yang baik (Febriati et al., 2019; Hastuti dan Budianti, 2014; Herawati et al., 2019; Syaepudin dan Juhji, 2020; Septantiningtyas et al., 2021). Selain itu, pembelajaran daring juga mampu merekam jejak penggunaan materi yang disampaikan. Guru dan peserta didik dapat merekam materi yang disampaikan secara mudah dan dapat digunakan pada waktu-waktu yang lain jika dibutuhkan kembali. Terakhir, pembelajaran daring mampu mengkonstruk pengetahuan peserta didik (Zhafira et al., 2020). Kontruksi pengetahuan perlu dikembangkan oleh guru karena sejatinya peserta didik sudah memiliki pengetahuan sebelum mereka mengikuti pembelajaran daring. Pengetahuan tersebut perlu dikonstruk agar peserta didik terbiasa membangun pengetahuan sendiri melalui serangkaian peristiwa dan pengalaman belajar mereka masing-masing.

\section{PENUTUP/SIMPULAN}

Pandangan guru sekolah menengah pertama terhadap pembelajaran daring bervariasi. Sebagian besar berkategori sedang dan sebagian kecil berkategori tinggi. Pandangan guru menyimpulkan bahwa pembelajaran daring mampu meningkatkan layanan pendidikan, meningkatkan keterjangkauan layanan pendidikan, meningkatkan mutu dan relevansi layanan pendidikan, meningkatkan kemandirian dan tanggung jawab peserta didik, memungkinkan interaksi langsung di media yang digunakan, mengkreasikan dan menginovasi metode pembelajaran yang digunakan, meningkatkan keterjaminan mendapatkan mutu layanan pendidikan yang baik, 
merekam jejak penggunaan materi yang disampaikan, dan mampu mengkonstruk pengetahuan peserta didik. Penelitian lanjutan perlu dilakukan.

\section{DAFTAR PUSTAKA}

Ahmad, A. (2020). Peningkatan Kompetensi Pedagogik Guru dalam Pembelajaran Jarak Jauh Melalui Pendampingan Sistem Daring, Luring, atau Kombinasi pada Masa New Normal Covid-19. Jurnal Paedagogy, 7(4), 258-264.

Asmuni, A. (2020). Problematika Pembelajaran Daring di Masa Pandemi Covid-19 dan Solusi Pemecahannya. Jurnal Paedagogy, 7(4), 281-288.

Febriati, Y., Saefurohman, A., \& Juhji, J. (2019). Efektivitas Penerapan Model Children Learning in Science terhadap Pemahaman Konsep IPA. Ibtida'i: Jurnal Kependidikan Dasar, 6(1), 29-40.

Hasbullah, H., Juhji, J., \& Ali, M. (2019). Strategi belajar mengajar dalam upaya peningkatan hasil belajar pendidikan agama islam. Edureligia, 3(1), 17-24.

Hastuti, A., \& Budianti, Y. (2014). Pengaruh Penggunaan Media Audio Visual Terhadap Hasil Belajar Siswa Pada Mata Pelajaran IPA Kelas II SDN Bantargebang II Kota Bekasi. Pedagogik (Jurnal Pendidikan Sekolah Dasar), 2(2), 33-38.

Herawati, L., Saefurohman, A., \& Juhji, J. (2019). Pengaruh Metode Eksperimen Terhadap Pemahaman Konsep Siswa MI Pada Materi Sifat dan Perubahan Wujud Benda. Primary: Jurnal Keilmuan Dan Kependidikan Dasar, 11(01), 69-76.

Hutauruk, A. J. (2020). Kendala pembelajaran daring selama masa pandemi di kalangan mahasiswa pendidikan matematika: Kajian kualiatatif deskriptif. Sepren, 2(1), 45-45.

Juhji, J. (2016). Peran Urgen Guru dalam Pendidikan. Studia Didaktika: Jurnal IImiah Bidang Kependidikan, 10(1), 52-62.

Kementerian Pendidikan dan Kebudayaan. (2014). Panduan Pengembangan dan Penyelenggaraan KDITT. Kemdikbud.

Khasanah, F. N., \& Sari, R. (2021). Pelatihan Mentimeter Sebagai Media Interaksi Dalam Pembelajaran Daring Pada SMAN 14 Bekasi. Journal of Computer Science Contributions (JuCosCo), 1(1), 42-52.

Kheryadi, K. (2018). The Implementation of "Whatsapp" as a Media of English Language Teaching. Loquen: English Studies Journal, 10(2), 1-14.

Kinloch, V., Burkhard, T., \& Graham, D. (2020). Storying youth lives: Centering equity in teaching and teacher education. International Journal of Qualitative Studies in Education, 33(1), 66-79. 
Kurnia, D. (2021). Dinamika Gejala Kejenuhan Belajar Siswa Pada Proses Belajar Online Faktor Faktor Yang Melatarbelakangi Dan Implikasinya Pada Layanan Bimbingan Keluarga. Teaching: Jurnal Inovasi Keguruan Dan IImu Pendidikan, 1(1), 1-10.

Mustofa, M. I., Chodzirin, M., Sayekti, L., \& Fauzan, R. (2019). Formulasi model perkuliahan daring sebagai upaya menekan disparitas kualitas perguruan tinggi. Walisongo Journal of Information Technology, 1(2), 151-160.

Nahdi, D. S., \& Jatisunda, M. G. (2020). Analisis literasi digital calon guru SD dalam pembelajaran berbasis virtual classroom di masa pandemi covid-19. Jurnal Cakrawala Pendas, 6(2).

Naserly, M. K. (2020). Implementasi Zoom, Google Classroom, Dan Whatsapp Group Dalam Mendukung Pembelajaran Daring (Online) Pada Mata Kuliah Bahasa Inggris Lanjut (Studi Kasus Pada 2 Kelas Semester 2, Jurusan Administrasi Bisnis, Fakultas Ekonomi Dan Bisnis, Universitas Bina Sa. Aksara Public, 4(2), 155-165.

Ningrum, D. W., Elqosamah, N. A., Mahareka, R., Cahyaningrum, D. E. N., \& Mujazi, M. (2020). Inovasi Belajar Daring Pada Masa Pandemi. Seminar Nasional Ilmu Pendidikan Dan Multi Disiplin 3 (SNIPMD 3). ISBN: 978-623-6566-35-0, 3.

Nuangchalerm, P., Prachagool, V., Prommaboon, T., Juhji, J., Imroatun, I., \& Khaeroni, K. (2020). Views of primary Thai teachers toward STREAM education. Int. J. Eval. \& Res. Educ. Vol, 9(4), 987-992.

Nurhasanah, P. S. (2020). Manajemen Pembelajaran Daring Di Musim Pandemi Covid-19 (studi Kasus Madrasah Ibtidaiyah Terpadu Al-Madinah Balong Ponorogo Tahun Pelajaran 2019/2020) [Thesis]. Universitas Muhammadiyah Ponorogo.

Omeri, N. (2015). Pentingnya pendidikan karakter dalam dunia pendidikan. Manajer Pendidikan, 9(3).

Pawicara, R., \& Conilie, M. (2020). Analisis pembelajaran daring terhadap kejenuhan belajar mahasiswa Tadris Biologi IAIN Jember di tengah pandemi Covid-19. ALVEOLI: Jurnal Pendidikan Biologi, 1(1), 29-38.

Pohan, A. E. (2020). Konsep pembelajaran daring berbasis pendekatan ilmiah. Penerbit CV. SARNU UNTUNG.

Prachagool, V., Nuangchalerm, P., Subramaniam, G., \& Dostál, D. (2016). Pedagogical decision making through the lens of teacher preparation program. Journal for the Education of Gifted Young Scientists, 4(1), 41-52.

Putria, H., Maula, L. H., \& Uswatun, D. A. (2020). Analisis proses pembelajaran dalam jaringan (daring) masa pandemi covid-19 pada guru sekolah dasar. Jurnal Basicedu, 4(4), 861-870. 
Rigianti, H. A. (2020). Kendala Pembelajaran Daring Guru Sekolah Dasar Di Banjarnegara. Elementary School: Jurnal Pendidikan Dan Pembelajaran KeSD-An, 7(2).

Rosenberg, H., \& Asterhan, C. S. (2018). “WhatsApp, Teacher?”-Student Perspectives on Teacher-Student WhatsApp Interactions in Secondary Schools. Journal of Information Technology Education: Research, 17, 205-226.

Rukiyati, R., Sutarini, Y. C. N., \& Priyoyuwono, P. (2014). Penanaman nilai karakter tanggung jawab dan kerja sama terintegrasi dalam perkuliahan ilmu pendidikan. Jurnal Pendidikan Karakter, 2.

Santika, I. W. E. (2020). Pendidikan karakter pada pembelajaran daring. Indonesian Values and Character Education Journal, 3(1), 8-19.

Septantiningtyas, N., Juhji, J., Sutarman, A., Rahman, A., \& Sa'adah, N. (2021). Implementation of Google Meet Application in the Learning of Basic Science in the Covid-19 Pandemic Period of Student Learning Interests. Journal of Physics: Conference Series, 1779(1), 012068.

Supardi, S., Juhji, J., Azkiyah, I., Muqdamien, B., Ansori, A., Kurniawan, I., \& Sari, A. F. (2021). The ICT basic skills: Contribution to student social media utilization activities. International Journal of Evaluation and Research in Education (IJERE), 10(1), 222-229.

Surani, D., \& Chaerudin, A. (2019). Pemanfaatan Media Whatsapp Grouping dalam Peningkatan Kemampuan Bahasa Inggris Ekonomi Mahasiswa Fakultas Ekonomi dan Bisnis. Tarbawi: Jurnal Keilmuan Manajemen Pendidikan, 5(02), 155-172.

Syaepudin, S., \& Juhji, J. (2020). The Effect of Using Powerpoint Media on Student Learning Outcomes in the Material Adaptation of Living Things. Pedagogi: Jurnal Penelitian Pendidikan, 7(1).

Syarifudin, A. S. (2020). Impelementasi Pembelajaran Daring Untuk Meningkatkan Mutu Pendidikan Sebagai Dampak Diterapkannya Social Distancing. Jurnal Pendidikan Bahasa Dan Sastra Indonesia Metalingua, 5(1), 31-34.

Tarihoran, N. M., \& Cendana, W. (2020). Upaya guru dalam adaptasi manajemen kelas untuk efektivitas pembelajaran daring. Jurnal Perseda: Jurnal Pendidikan Guru Sekolah Dasar, 3(3), 127-133.

Tondeur, J., Scherer, R., Baran, E., Siddiq, F., Valtonen, T., \& Sointu, E. (2019). Teacher educators as gatekeepers: Preparing the next generation of teachers for technology integration in education. British Journal of Educational Technology, 50(3), 1189-1209.

Widayati, S., Hotimah, N., \& Rakhmawati, N. I. S. (2020). Respon Mahasiswa Pada Proses Pembelajaran Mata Kuliah Daring. Child Education Journal, 2(1), 4852. 
Widodo, A., \& Nursaptini, N. (2020). Problematika Pembelajaran Daring dalam Perspektif Mahasiswa. ELSE (Elementary School Education Journal): Jurnal Pendidikan Dan Pembelajaran Sekolah Dasar, 4(2), 100-115.

Yohana, Y. Y., Muzakir, M., \& Hardianti, D. (2020). Efektivitas Pembelajaran Daring Pada Program Studi Pendidikan Ekonomi Koperasi Fakultas Keguruan Dan IImu Pendidikan Universitas Qamarul Huda Badaruddin. TIRAI EDUKASI: Jurnal Pendidikan, 1(4).

Zhafira, N. H., Ertika, Y., \& Chairiyaton, C. (2020). Persepsi mahasiswa terhadap perkuliahan daring sebagai sarana pembelajaran. Jurnal Bisnis Dan Kajian Strategi Manajemen, 4(1). 